\title{
Volatilization of Fission Products from Metallic Melts in the Melt-Dilute Treatment Technology Development for Al-Based DOE Spent Nuclear Fuels
}

by

T. Adams

RECORDS ADMINISTRATION

Westinghouse Savannah River Company

Savannah River Site

Aiken, South Carolina 29808
A. J. Duncan
H. B. Peacock

A document prepared for MRS FALL MEETING at Boston, MA, USA from 11/28/99 - 12/3/99.

DOE Contract No. DE-AC09-96SR18500

This paper was prepared in connection with work done under the above contract number with the U. S.

Department of Energy. By acceptance of this paper, the publisher and/or recipient acknowledges the U. S. Government's right to retain a nonexclusive, royalty-free license in and to any copyright covering this paper, along with the right to reproduce and to authorize others to reproduce all or part of the copyrighted paper. 


\section{DISCLAIMER}

This report was prepared as an account of work sponsored by an agency of the United States Government. Neither the United States Government nor any agency thereof, nor any of their employees, makes any warranty, express or implied, or assumes any legal liability or responsibility for the accuracy, completeness, or usefulness of any information, apparatus, product or process disclosed, or represents that its use would not infringe privately owned rights. Reference herein to any specific commercial product, process or service by trade name, trademark, manufacturer, or otherwise does not necessarily constitute or imply its endorsement, recommendation, or favoring by the United States Government or any agency thereof. The views and opinions of authors expressed herein do not necessarily state or reflect those of the United States Government or any agency thereof.

This report has been reproduced directly from the best available copy.

Available for sale to the public, in paper, from: U.S. Department of Commerce, National Technical Information Service, 5285 Port Royal Road, Springfield, VA 22161

phone: (800) 553-6847

fax: (703) 605-6900

email: orders@ntis.fedworld.gov

online ordering: http://www.ntis.gov/ordering.htm

Available electronically at http://www.doe.gov/bridge

Available for a processing fee to U.S. Department of Energy and its contractors, in paper, from: U.S. Department of Energy, Office of Scientific and Technical Information, P.O. Box 62, Oak Ridge, TN 37831-0062

phone: (865)576-8401

fax: (865)576-5728

email: reports@adonis.osti.gov 


\title{
Volatilization of Fission Products from Metallic Melts in the Melt-Dilute Treatment Technology Development for AI-Based DOE Spent Nuclear Fuels
}

\author{
Thad M. Adams, Andrew J. Duncan, and Harold B. Peacock, Jr. \\ Westinghouse Savannah River Company \\ Savannah River Technology Center \\ Aiken, SC 9808
}

\section{Introduction}

The melt-dilute treatment technology is being developed to facilitate the ultimate disposition of highly enriched Al-Base DOE spent nuclear fuels in a geologic repository such as that proposed for Yucca Mountain. Currently, approximately 28 MTHM is expected to be returned to the Savannah River Site from domestic and foreign research reactors. The melt-dilute treatment technology will melt the fuel assemblies to reduce their volume and alloys them with depleted uranium to isotopically dilute the ${ }^{235} U$ concentration. The resulting alloy is cast into a form for long term geologic repository storage. Benefits accrued from the melt-dilute process include the potential for significant volume reduction; reduced criticality potential, and proliferation concerns

A critical technology element in the development of the melt-dilute process is the development of offgas system requirements. The volatilization of radioactive species during the melting stage of the process primarily constitutes the offgas in this process. Several of the species present following irradiation of a fuel assembly have been shown to be volatile or semi-volatile under reactor core melt-down conditions. Some of the key species that have previously been studied are krypton, iodine, and cesium. All of these species have been shown to volatilize during melting experiments however, the degree to which they are released is highly dependent upon atmosphere, fuel burnup, temperature, and fuel composition. With this in mind an analytical and experimental program has been undertaken to assess the volatility and capture of species under the melt-dilute operating conditions.

\section{Melt-Dilute Program Development}

A typical irradiated research and test reactor fuel assembly contains more than 100 chemical species that include fission products, actinides, and light elements. Table 1 displays a listing of the key radiological and non-radiological elements that have been analytically predicted to volatilize during treatment of DOE SNF using the melt-dilute technology. From this listing it can be seen that of all the radiological elements predicted to be volatile the $\mathrm{Cs}-137$ and $\mathrm{Kr}-85$ results in the greatest mass and activity. Thus, with respect to offgas system development the trapping and maintenance of Cs-137 and $\mathrm{Kr}-85$ will be the initial focus.

Table 1 Listing of the Key Radiological and Non-Radiological Volatile Elements

\begin{tabular}{|l|c|c|}
\hline Element & Mass $(\mathrm{g})$ & Curies \\
\hline Antimon & 0.0002 & 0.042 \\
\hline Barium & 0.011 & $<\mathrm{E}-11$ \\
\hline Bromine & 0.176 & 0 \\
\hline Cesium & 19.3 & 817 \\
\hline Cadmium & 0.134 & 0.06 \\
\hline Europium & 0.0009 & 0.0193 \\
\hline Gadolinium & 0.00004 & $<\mathrm{E}-09$ \\
\hline
\end{tabular}




\begin{tabular}{|l|c|c|}
\hline Element & Mass (g) & Curies \\
\hline Iodine & 1.28 & 0.0002 \\
\hline Krypton & 3.64 & 72 \\
\hline Magnesium (NR) & 60 & 0 \\
\hline Manganese (NR) & 29 & 0 \\
\hline Rubidium & 3.54 & $<\mathrm{E}-07$ \\
\hline Samariu & 0.0012 & 0.0008 \\
\hline Strontium & 0.006 & 5.04 \\
\hline Tellurium & 0.456 & 0.43 \\
\hline Xenon & 0.422 & $<\mathrm{E}-21$ \\
\hline Zinc (NR) & 5 & 0 \\
\hline \multicolumn{2}{|l|}{ NR= Non-Radiological--i.e., Cladding Additions } \\
\hline
\end{tabular}

Conventional techniques for trapping krypton gas are commercially available. Currently, there are no commercially available techniques or devices for trapping volatile cesium. Hence, developing a process for trapping $\mathrm{Cs}$ is important and needs development.

Previous work [1] on the melt-refining of uranium metal EBR-II assemblies performed at ANL in the mid-60's has provided guidance with respect to the trapping of volatile cesium from metallic melts. In these experiments, sodium bonded uranium metal EBR-II assemblies were melted at temperatures on the order of $1200^{\circ} \mathrm{C}$. Like U-Al fuels, the major volatile component of these EBR-II fuels was cesium. As a result, bench-scale experiments were conducted to assess a suitable means of trapping cesium vapor and particulate. Several packed granular beds consisting of various media including activated alumina, activated carbon, molecular sieves, magnesia, zirconia, and silica gel were tested at temperatures from $500-800^{\circ} \mathrm{C}$. From these experiments, three of the media-activated alumina, activated carbon, and molecular sieves-appeared suitable for preventing cesium breakthrough of the packed bed. Thus, these cesium absorbing media will serve as the basis for the fundamental experimental melt-dilute offgas development effort.

\section{Experimental Program}

The approach to the development and design of the melt-dilute offgas system has been incremental in nature as shown in Figure 1. The development program began with bench-scale non-radioactive surrogates. Much of the cesium was observed to remain in the crucible, bulk metal, or in the oxide layer on the surface of the metallic melt $[2,3]$. These tests provided screening of different absorber media and absorber bed configurations on a sample size approximately $1 / 10^{\text {th }}$ that of a full-scale SNF assembly. Based on the output of the bench-scale surrogate tests, a full-scale surrogate offgas system and furnace were developed for further testing and validation. This apparatus was capable of testing full-scale surrogate SNF assemblies containing representative concentration of total cesium. Simultaneous with these full-scale surrogate tests, a bench-scale irradiated SNF coupon test was conducted to assess the impact of irradiation on the offgas behavior. These tests were performed at ÁNL with coupons of irradiated U-Al RERTR fuels in a furnace and offgas system similar to our bench-scale surrogate apparatus. This paper will provide the results from the full-scale surrogate and irradiated SNF coupon tests. 


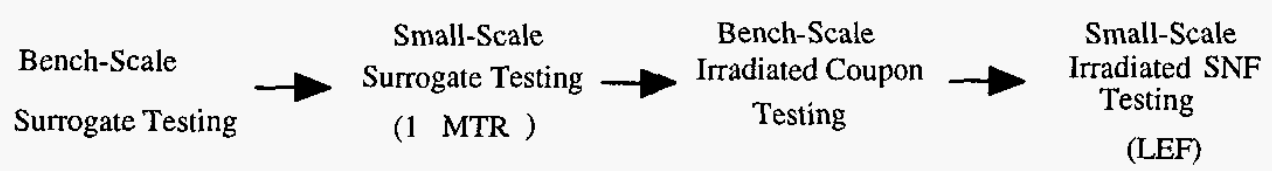

Figure 1 Development Path for the Melt-Dilute Treatment Technology Offgas System

\section{Experimental Methods}

\section{SRTC Small Scale Tests}

Following the bench-scale screening tests, an integrated melt-dilute treatment apparatus was developed as shown in Figure 2. This apparatus consisted of a $125 \mathrm{~kW}$ induction furnace and stirring unit with an offgas system made up of an absorber bed, water scrubber, silica gel dryer, a HEPA filter, and two vacuum pumps. This system was designed to be versatile in nature in that it is capable of accommodating several different absorber bed designs and positions.

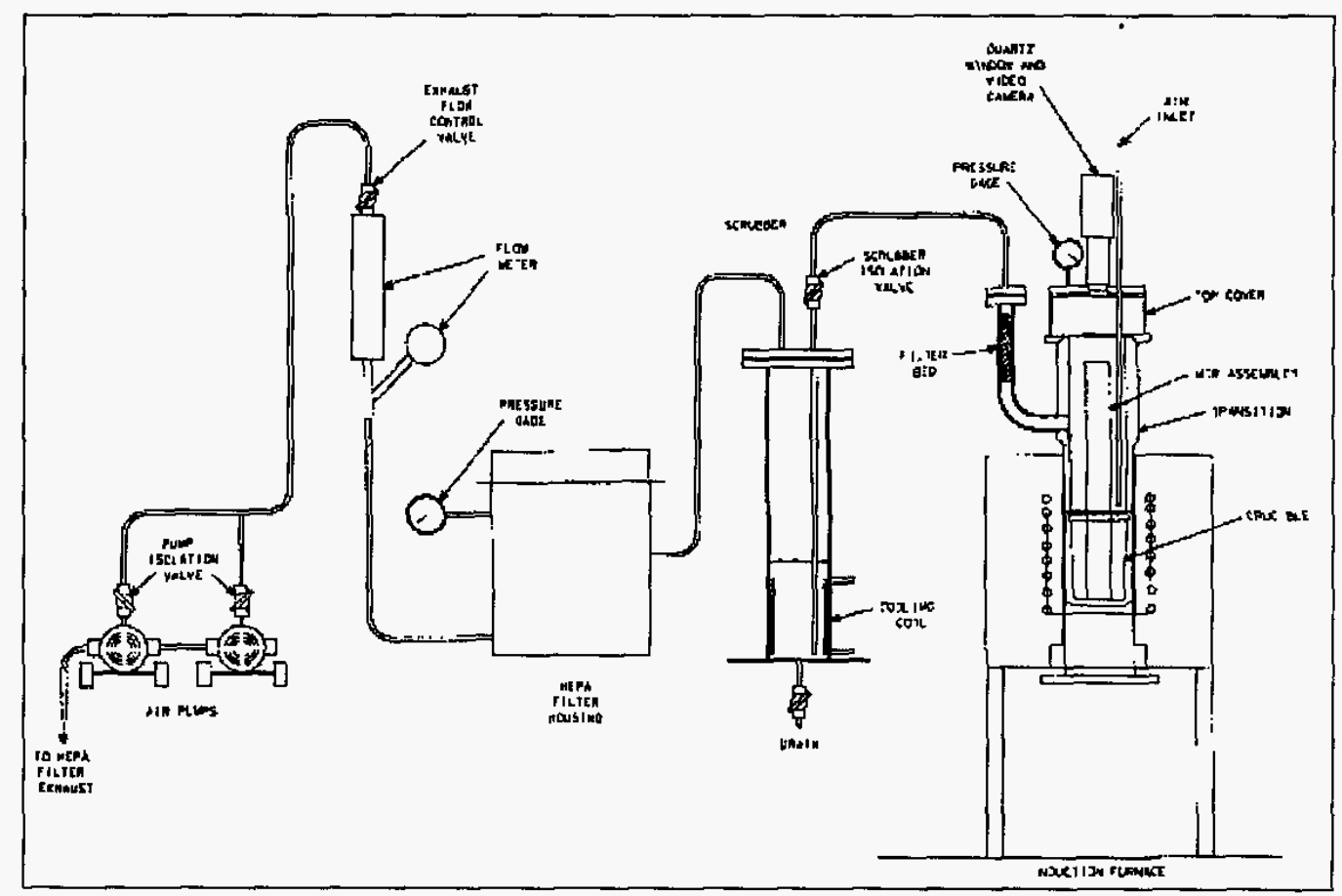

Figure 2 Integrated Melt-Dilute Treatment Apparatus

The approach to the experiments conducted on this full-scale system was similar to the bench scale system with the ultimate goal being to develop an absorber bed that has a performance efficiency of $100 \%$-i.e., allows zero break-through. Surrogate SNF assemblies doped with cesium carbonate as the cesiu surrogate were fabricated in the Materials Laboratory at SRTC. These mock SNF assemblies were melted at $850^{\circ} \mathrm{C}$ in the full-scale apparatus and held at 
temperature for times on the order of 1 hour. Following this treatment cycle, the melt was allowed to solidify in the crucible and then the entire system was dismantled and each piece washed with either deionized water or dilute nitric acid. These wash samples were analyzed for cesium content using atomic absorption spectroscopy.

\section{Irradiated Testing}

Bench-Scale irradiated coupon tests have been performed at the Alpha-Gamma Hot Cells at ANL-E. These tests were performed as indicators to the behavior of irradiated materials with respect to both process melting and offgas behavior. The relatively small sample size and fission product loading makes these tests valuable only to general behavioral trends and not as relative absolutes. An apparatus was designed by SRTC and ANL-E personnel to simulate as close as possible the melt-dilute treatment conditions as tested in the full-scale surrogate experiments. One major difference, however, was the absence of any stirring-mechanical or induction - of the melt-pool in the irradiated coupon test. The apparatus contained a graphite crucible for melting the SNF coupons and a zeolite 4A-absorber bed approximately 1 inch in diameter and 5 inches long. The airflow in the test assembly was held constant at $10 \mathrm{scfh}$. At the outlet side of the zeolite absorber bed a water bubbler was inserted to monitor for bed break-through.

\section{Results and Discussion}

\section{SRTC Small Scale Testing:}

From the series of experiments conducted at $850^{\circ} \mathrm{C}$ in the full-scale apparatus and held at temperature for times on the order of 1 hour the results for the system efficiency were established. The performance efficiency values were determined by examining the percentage difference between the cesium found in the wet scrubber and the tubing connecting the bed and scrubber compared to the initial cesium loading of the surrogate MTR. These relative efficiency values are reported in Table 2. Once again as in the bench-scale results the uncertainty for these measurements is approximately $0.01 \%$ based on the sensitivity of the atomic absorption cesiu analysis of the liquid wash samples. The results of these experiments indicate that the offgas system with the concentric ring bed design is the most consistently effective at containing cesium. Additionally, the release fractions from these melt-experiments are higher than the bench-scale tests most likely due to stirring, however are they are still within the range of $5 \%$ reported by Taleyarkhan [4].

\section{Irradiated Testing}

Bench-Scale irradiated coupon tests have been performed at the Alpha-Gamma Hot Cells at ANL-E. These tests were performed as indicators to the behavior of irradiated materials with respect to both process melting and offgas behavior. The gamma scan for the test assembly is shown in Figure 3. The scan starts below the specimen chamber and continues up past the filter chamber. The top curve shows the gross activity and the bottom shows the Cs-137 activity; there is some background signal from the hot cell that accounts for the approximately 20,000 counts seen as the baseline of the gross activity curve. Both curves show two peaks, the larger peak is associated with the specimen chamber. There is a slightly elevated section just above the specimen chamber (from the 5-8 in. mark), which is probably due to some Cs-137 plating out on the stainless steel tubing during the cool-down. In the absorber bed chamber, there are two Cs peaks present a small peak followed by a larger peak. The smaller peak may be associated with 
Cs fines that were trapped in the steel screen, located at the bottom of the filter to retain the filter media. No activity is seen above the absorber bed.

Table 2 Full-Scale Surrogate Testing Offgas Efficiency Results

\begin{tabular}{|c|c|c|c|c|}
\hline Bed Design & Test Conditions & System Efficiency \% & \% Volatilized & Mass Balanc \\
\hline Straight Pass & Side Exit, 1scf & 99.17 & 3.13 & 26.97 \\
\hline Straight Pass & Side Exit, Iscf & 97.92 & 5.21 & 37.92 \\
\hline Straight Pass & Side Exit, 1scf & 97.65 & 6.40 & 54.89 \\
\hline Straight Pass & Side Exit, 1scf & 97.86 & 5.19 & 53.68 \\
\hline Straight Pass & Side Exit, 6 scf & 98.31 & 3.93 & 61.05 \\
\hline Straight Pass & Top Exit, $1 \mathrm{scfm}$ & 97.55 & 3.71 & 50.50 \\
\hline Straight Pass & Top Exit, $1 \mathrm{scfm}$ & 98.45 & 3.35 & 54.38 \\
\hline Radial Plate & $1 \mathrm{scfm}$ & 99.34 & 2.35 & 59.36 \\
\hline Radial Plate & 1scfm, Cs metal & 94.34 & 27.65 & 52.80 \\
\hline Concentric Ring & $1 \mathrm{scfm}$ & 99.89 & 2.35 & 26.10 \\
\hline Concentric Ring & $1 \mathrm{scfm}$ & 99.99 & 0.51 & 13.68 \\
\hline
\end{tabular}

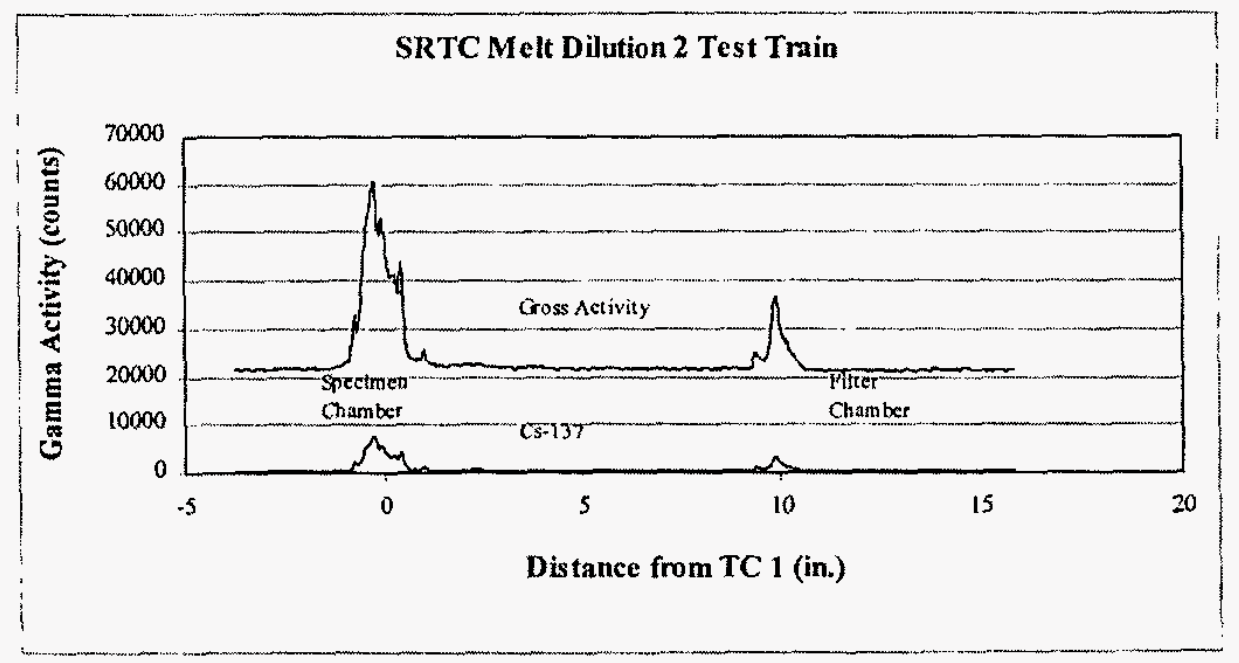

Figure 3 Gamma Scan for the entire Bench Scale Irradiated Testing Apparatus

About $78 \%$ of the Cs-137 remained in the specimen chamber, $16 \%$ was trapped in the filter and approximately $6 \%$ was plated out on the stainless steel tube just above the specimen chamber. The total release fraction for this experiment is approximately $22 \%$. This value is greater than the values reported by Taleyarkhan and for most of our SRTC test, however, this value is consistent with previous SNF coupon melt studies performed at Hanford. 


\section{Summary}

The major findings from the full-scale experiments were that stirring of the melt appears to minimally increase the volatilization of cesium from the melt. Of the three-absorber bed designs tested the baffled concentric ring design provided the best and most reproducible efficiencies. However, the design as tested did not provide zero breakthrough. As a result, the absorber bed that is being designed for the full-scale irradiated facility will be of the same basic design with a $50 \%$ increase in bed volume to attempt to achieve zero breakthrough.

The results from the bench-scale irradiated SNF coupon have provided further confirmation as to the effectiveness of a zeolite absorber bed to trap volatile cesium. No evidence of bed break through was detected. Additionally, these results provide further validation to fundamental analytical calculations for predicting volatile species from the melt-dilute process. According to these calculations cesium would be the major volatile of concern and in the bench-scale irradiated coupon test the only radionuclide detected in any part of the test assembly using gamma scanning was cesium. Furthermore, although more cesium was released from this irradiated coupon melt than in previous bench and full scale surrogate tests, the amount volatilized was still below the maximum cesium release reported in the literature. Finally, the behavior documented from this irradiated coupon melt fully supported/validated all of the surrogate melt studies.

Lastly, the final step in the development and design of the melt-dilute offgas system will culminate with a full-scale irradiated melt-dilute facility at the Savannah River Site. This facility will be capable of melting full-scale irradiated SNF assemblies and will possess a prototypical offgas system that has been initially designed based on the bench and full-scale surrogate and bench-scale irradiated offgas experiments.

\section{Acknoledgements}

This work was supproted by the U. S. Department of Energy under contract No. DE-AC0996SR18500. The authors would also like to thank Adam Cohen and his staff at the Alpha Gamma Hot Cells at Argonne National Laboratory for conducting the irradiated SNF coupon test.

\section{References}

$1 \mathrm{~J}$. Wolkoff and A. Chilenskas, "The Melt Refining of Irradiated Uraniu : Application to EBR II Fast Fuel, IX, "Sorption and Retention of Sodium and Cesium Vapor on Stationary Beds at Elevated temperature," Nuclear Science and Engineering, 9, pp 71-77 (1961).

2 T. M. Adams et al, The Melt-Dilute Treatment Technology Offgas Development Status Report, WSRC-TR-99-00145, April, 1999.

3 M. E. Hodges and M. L.Hyder, "Offgas-Studies for the Melt-Dilute Program", ANS Third Topical Meeting, DOE Spent Nuclear Fuel and Fissile Materials Management, Charleston, SC, September 8-11, 1998.

4 R. P. Taleyarkhan, "Analysis and Modeling of Fission Product Release from Various UraniumAluminum Plate-Type Reactor Fuels," Nuclear Safety, Vol. 33, No. 1, January-March 1992. 